\title{
Papillomavirus Transforming Protein E7
}

National Cancer Institute

\section{Source}

National Cancer Institute. Papillomavirus Transforming Protein E7. NCI Thesaurus. Code C19171.

Complexes with and inactivates $\mathrm{Rb}$ protein resulting in disruption of cell cycle regulation. 